\title{
CST1 wt Allele
}

National Cancer Institute

\section{Source}

National Cancer Institute. CST1 wt Allele. NCI Thesaurus. Code C159785.

Human CST 1 wild-type allele is located in the vicinity of 20p11.21 and is approximately 4 $\mathrm{kb}$ in length. This allele, which encodes cystatin-SN protein, is involved in the inhibition of papain, cathepsin $\mathrm{C}$ and ficin. 